\title{
DOUBLE TRACK CRIMINAL SYSTEM OF INDONESIA: CRIMINAL SANCTION AND CHEMICAL CASTRATION TREATMENT POLICY ON PEDHOFILIA?
}

\author{
${ }^{1}$ Appludnopsanji, ${ }^{2}$ Ani Purwanti \\ ${ }^{1}$ Faculty of Law, Universitas Diponegoro, Semarang, Indonesia, appludnopsanji96@gmail.com \\ ${ }^{2}$ Faculty of Law, Universitas Diponegoro, Semarang, Indonesia, ani_purwanti81@yahoo.com
}

\begin{abstract}
Cases of sexual contact with threats or violence perpetrated against children by adult offenders may be subject to criminal penalties and treatment of chemical castration. This is governed by Law No. 17 of 2016, which passed the Government Regulation in lieu of Law No. 17 of 2016. The existence of criminal sanctions and acts in the form of chemical castration is a breakthrough and a manifestation of the implementation of double-track sentencing. The chemical castration treatment has led to the opposition of society. Consequently, to find out how the regulation of chemical castration treatment and to know what chemical castration is appropriate with the double-track criminal system. It is necessary to researching doctrinal research. The results showed that chemical castration is an treatment and castration has been contradicted with the double-track criminal system adopted by Indonesia.
\end{abstract}

Keywords: Criminal Sanction; Chemical Castration Treatment; Double-Track System

\section{Introduction}

Indonesia has happened many changes in the field of law at the moment. One of the changes occurred in the field of criminal law. The development of criminal law can be seen in manifesting the perpetrators from a criminal orientation to punishment. The criminal sanctions of criminal law originally was only for retribution for the act of the perpetrator. Today, not just for vengeance, but also to provide protection for criminals to become successful in the future, such as treatment, is the progression of criminal law. This is classified as a criminal sanction using either a two-track system or a double-track system. ${ }^{1}$

Indonesian Penal Code is commonly familiar with criminal sanctions and penalties for conduct, namely those found in Article 10 of the Criminal Code relating to forms of criminal sanctions, while the law contained in Articles 44, 45, 46 of the Criminal Code are concerned. It is undeniable that Indonesian material criminal law is being used now or that the Criminal Code has not been able to be maximized because it has been codified for too long and can't summarize all legal issues in the criminal field, so then the enactment of special crime law that accommodates all special legal events. The presence outside of the Criminal Code of special

\footnotetext{
1 Aisyah Amini Burhanuddin, "Penerapan Sistem Dua Jalur Dalam Putusan Perkara Anak Yang Berhadapan
} Dengan Hukum," Al Hikam 2, no. 1 (2018): 34-49. 
criminal law and criminal law is a representation that criminal law wishes to achieve, especially in the effort to deal with crime. This effort to prevent crime can't be eliminated from the name of a crime prevention policy in the form of regulations made by the authorities that are an integral part of social policy for achieving social welfare and protection of the community. ${ }^{2}$

The sentencing of a criminal sentence using double-track system, constitutes a sentence in the form of a criminal offense and an treatment against the accused. Such sentences are based on abandoning previous weaknesses by abandoning the traditional approach and giving rise to good advantages and aims in which such a system is a system that has been applied internationally and as a source of Neo-classical schools in criminal law. ${ }^{3}$

The presence of Law Number 35 of 2014 concerning amendments to Law Number 23 of 2002 concerning Protection of Children to guarantee and protect children's welfare including protection of children's rights from violence and inhuman discrimination. This law adheres to the name of the double-track system that discusses the existence of criminal sanctions and treatment. Criminal sanctions are intended for perpetrators whose aim is to deter perpetrators, while treatment is given to children as victims for the recovery of conditions for children. This can be found in Law No. 35 of 2014, namely in Articles 81 to 89 concerning criminals and Article 69A regarding these treatment. Nevertheless, it has not yet been identified that criminal sanctions and treatment are being enforced on perpetrators whose purpose is not only to turn over the perpetrators but to handle the perpetrators so that they do not do so again in the future.

On 9 November 2016, Law No. 17 of 2016 on the Stipulation of Government Regulation Replaced Law No. 1 of 2016 on the Second Amendment to Law No. 23 of 2002 on Child Protection Becomes an Treatment. This law was born because there was an urgent condition in Indonesia that sexual violence against children would be a matter of emergency, originally referred to as Government Regulation in Instead of Law No 1 of $2016 .{ }^{4}$ As a result of Indonesia's emergency conditions of sexual violence against children and the number of cases of sexual violence against children each year has increased and it is judged that there is still a lack of punishment for perpetrators of sexual violence against children and that it does not deter perpetrators except under these rules, The State is present to guarantee children's right to survival, growth and development, as well as protection from violence and discrimination.

\footnotetext{
Barda Nawawi Arief, Bunga Rampai Kebijakan Hukum Pidana (Semarang: Prenadamedia Group, 2018). Muladi Muladi and Barda Nawawi Arief, Teori-Teori Dan Kebijakan Pidana (Bandung: Alumni, 2010).

4 Nabila Tashandra, "DPR Sahkan Perppu Kebiri Menjadi Undang-Undang," n.d., https://nasional.kompas.com/Read/2016/10/12/13333281/Dpr.Sahkan.Government Regulation In Lieu Of Law.Kebiri.Menjadi.Undang-Undang?Page=All.
} 
Explicitly, the contents of the article in the regulation are already present in it the concept of the double-track system. Where there are criminal sanctions and treatment imposed on perpetrators of sexual violence against children. As an example contained in the contents of Article 81 paragraphs (1) and (7) Government Regulation in Instead of Law No 1 of 2016. In paragraph 1 it explains that every person who violates the provisions of Article 76D shall be sentenced to a maximum imprisonment of 5 (five) years and a maximum of 15 (fifteen) years and a maximum fine of Rp.5,000,000,000.00 (five billion rupiahs). Paragraph (7) explains that the perpetrators as referred to in paragraph (4) and paragraph (5) may be subject to treatment in the form of chemical castration and the installation of electronic detection devices. From the two verses already appear criminal sanctions and treatment in it, but seen from the concept of the double-track system whether the treatment in the form of chemical castration is appropriate and equivalent to criminal sanctions needs to be studied in depth in the current author's research.

This research focuses on treatment in the form of chemical castration. This research has been studied by several people including Nuzul Qur'aini Mardiya in 2017. ${ }^{5}$ This research focuses on the application of chemical castration sanctions for perpetrators of sexual violence, Nur Hafizal Hasanah and Eko Supoyono in 2018. ${ }^{6}$ The title of research on criminal law policy on chemical castration sanctions and the perspective of human rights and law Indonesian criminal. and has been investigated by Cesar Antonio Munthe in 2016 which focuses on the relevance of chemical castration sanctions in Government Regulation in Lieu of Law number 1 of 2016 on the second amendment to law number 23 of 2002 concerning the protection of children against criminal purposes. ${ }^{7}$ Based on previous research, there are differences in the focus of research to be conducted by the author with previous researchers. Although, It looks same about chemical castration, the writer emphasizes the compatibility and equality of the basic idea of the doubletrack system between criminal sanctions and treatment of chemical castration that occur in Indonesia. In the context of the problem above, it is natural that this study moves around the question of how criminal law policy on treatment in the form of chemical castration at this time

5 Nuzul Qur'aini Mardiya, "Penerapan Hukuman Kebiri Kimia Bagi Pelaku Kekerasan Seksual Implementation Of Chemical Castration," Jurnal Konstitusi 14, no. 1 (2017): 214-33.

6 Nur Hafizal Hasanah and Eko Soponyono, "Kebijakan Hukum Pidana Sanksi Kebiri Kimia Dalam Perspektif Ham Dan Hukum Pidana Indonesia," Jurnal Magister Hukum Udayana (Udayana Master Law Journal) 7, no. 3 (2018): 305-17.

7 Cesar Antonio Munthe, "Relevansi Sanksi Kebiri Kimia Dalam Perpu No. 1 Tahun 2016 Tentang Perubahan Kedua Atas Undang-Undang Nomor 23 Tahun 2002 Tentang Perlindungan Anak Terhadap Tujuan Pemidanaan," Justitia Et Pax 32, no. 2 (2017): 106-22. 
and how criminal law policy on chemical castration treatment in the sense of the basic ideas of the concept of the double-track system.

\section{Methods}

Research is a basic effort and not just observing carefully an object that is easily held. This type of research used in this paper is doctrinal legal research because it examines the systematic regulation of laws and examines the synchronization of statutory regulation. The legal materials used in this study were obtained from secondary legal data sourced from library research.

The article uses secondary information in reading. Secondary data is indirect information derived from the research object's origin. Such details are in the form of legally binding material (primary legal content), Legal material providing further descriptions of primary legal material such as books, papers and internet related to the topic of this study (secondary legal material) and legal material providing a clarification of the above two legal materials (tertiary legal material), since this legal material is capable of clarifying the terms and problems that may arise; for example, is a legal dictionary and other language dictionaries. The technique used in secondary data collection is through library research or documentary study, which is a study that examines various documents related to both legislation and other available documents. The last step is to collect data-data that has been collected so that it becomes a legal writing that can address the questions that have been previously developed to help the reader draw a correct conclusion.

\section{Results and Discussion}

\subsection{Criminal Policy about Chemical Castration in Indonesia}

The legal policy problem about treatment of chemical castration can not be isolated from the widespread and large cases of sexual abuse that are now affecting Indonesian children. According to data from the LPSK (Witness and Victim Protection Agency) submitted by LPSK Deputy Chairperson Edwin Partogi Pasaribu data on child sexual abuse there was a substantial increase, including 25 cases in 2016, then rose to 81 cases in 2017, and the maximum in 2018 was 206, in 2019 was 123 cases. It was revealed that 80.23 percent of the perpetrators of sexual violence against children are dominated by the closest people, according to Ahmadi as the 
Deputy Chairperson of other LPSKs. In the meantime, $19.77 \%$ were carried out by unknown people. $^{8}$

Based on the data that it has occurred in Indonesia concerning cases of sexual violence against children, it is true that if it is now linked to laws and regulations, it is not able to respond to the existing problems, so that it has not been able to provide protection and prevention in order to not function properly. The penalty levied on sexual violence offenders did not have a deterrent effect on the individual and could not change the offender's act to become a better person. In this case, in 2016, President Joko Widodo released and signed a criminal law regulation on Government Regulation instead of Law No. 1 of 2016 relating to the Second Amendment to Law No. 23 of 2002 on Child Protection, which was subsequently approved by the legislature and became Law No. 17 of 2016 About the stipulation of Government Regulation instead of Law No. 1 of 2016 on Child Protection Amendment to Law No. 23 of 2002.9

Criminal law policy is an effort at one time to enforce good regulations according to the circumstances and situations. ${ }^{10}$ According to Sudarto, implementing criminal law politics means holding activities to make rules in order to achieve the best results of criminal legislation in the sense of meeting the requirements of justice and usability by circumstances and situations at a time and for the days to come. Criminal law enforcement policy is a series of processes that consist of three policy stages. First, the stage of formulating policy or legislative policy stage, namely the stage of criminal law formulation. Second, the stage of judicial/applicative policy, namely the stage of applying criminal law. Third, the executive / administrative policy stage, namely the stage of implementing/executing criminal law. ${ }^{11}$ The criminal law policy as outlined in Indonesia's child protection legislation has been amended by adding penalties and additional sentences regulated in Government Regulation instead of Law No. 1 of 2016 for perpetrators of sexual violence against children contained in Article 81(7) Government Regulation instead of Law No. 1 of 2016, namely: Actors as referred to in paragraph (4) and paragraph (5) may be subject to act in the form of chemical castration and installation of electronic detection devices. There is a period of 3 (three) years from the existence of the Treatment.

8 Arief Ikhsanudin, "KPAI Sebut Kasus Kekerasan Seksual Anak Meningkat Akibat Pengaruh Digital," n.d., https://news.detik.com/Berita/D-4640789/Kpai-Sebut-Kasus-Kekerasan-Seksual-Anak-Meningkat-AkibatPengaruh-Digital.

9 Lidya Suryani Widayati, "Pengebirian Sebagai Upaya Perlindungan Anak Dari Kekerasan Seksual," Info Singkat Hukum 7, no. 20 (2015): 1-4.

10 Junita Mokale, "Pedofilia Sebagai Salah Satu Bentuk Kejahatan Kekerasan Seksual Terhadap Anak," Lex Crimen 2, no. 5 (2013): 98-107.

11 Krismiyarsi Krismiyarsi, "Kebijakan Sanksi Kebiri Kimia Bagi Pelaku Kekerasan Seksual Terhadap Anak Kajian Politik Hukum Pidana,” Seminar Nasional Hukum Universitas Negeri Semarang 4, no. 1 (2018): 90-109. 
Chemical castration is conducted by injecting anti-androgen chemicals into the body of a person and the best way to treat child predator of sex and safe children from criminal. ${ }^{12}$ The goal is to reduce the hormone testosterone production. The end effect is similar to that of actual castration. ${ }^{13}$ Wimpie Pangkahila, professor at the Faculty of Medicine at Udayana University, said the word anti-hormone testosterone came from the chemical castration. The perpetrator is expected to lose sex drive through this drug so that he doesn't want to and can't do it anymore. ${ }^{14}$ However, sexual desire is not only affected by the testosterone hormone. Chemical castration has been investigated with the use of anti-androgens to lower testosterone levels in sexually risky males since the 1940s. Around two decades later, Dr. John Money became the first person in the United States to prescribe the drug Medroxyprogesterone Acetate (MPA) to sex offenders. While other chemical agents have been administered to such offenders worldwide, MPA is the most commonly administered drug in the U.S. for the purpose of chemical casting. ${ }^{15}$ There are other factors that promote this, including past sexual encounters, health conditions, and sexual function psychological factors. Therefore, the desire to have sexual intercourse will not necessarily completely disappear despite being given anti-testosterone drugs.

The implemention chemical castration treatment of Indonesia is further regulated in article 81A paragraph (1) Government Regulation in Lieu of Law No. 1 of 2016 namely: "The treatment as referred to in Article 81 paragraph (7) shall be imposed for a maximum period of 2 (two) years and to be carried out after the convict has served the principal crime". Execution of chemical castration treatment is agreed jointly with the main perpetrator, but after the major criminal treatments followed by rehabilitation, the execution of the chemical castration treatment is carried out. Chemical castration treatment with a maximum period of 2 (two) years and the implementation of chemical castration treatment under the Ministry of Law, Social, Health will be monitored. More detailed implementation procedures will be regulated by government

12 Vedije Ratkoceri, "Chemical Castration As A Security Measure In The Criminal Legislation Of The Republic Of Macedonia," International Journal Of Social Sciences And Education Research 3, no. 2 (2017): 357-60.

13 Supriyadi Widodo Eddyono, Ahmad Sofian, and Anugerah Rizki Akbari, Menguji Euforia Kebiri Catatan Kritis Atas Rencana Kebijakan Kebiri (Chemical Castration) Bagi Pelaku Kejahatan Seksual Anak Di Indonesia (Jakarta Selatan: Institue For Criminal Justice Reform Ecpat Indonesia Mappi FH UI Koalisi Perempuan Indonesia Aliansi 99 Tolak Perppu Kebiri, 2016).

14 Hasanah and Soponyono, "Kebijakan Hukum Pidana Sanksi Kebiri Kimia Dalam Perspektif Ham Dan Hukum Pidana Indonesia."

15 Elizabeth M Tullio, "Chemical Castration for Child Predators: Practical, Effective, and Constitutional," Chapman Law Review 13, no. 19 (2010): 191-220. 
regulations, but the detailed chemical castration treatment is unfortunately not regulated until now. ${ }^{16}$

The presence of this law has caused some circles of conflict, the conflict has arisen as a result of the addition of punishment in the form of chemical castration and electronic detection devices for sexual violence perpetrators (receive) against children and the position of the function from chemical castration. Despite of happen a contradictions about this treatment, in 2019 there was a court ruling namely the Mojokerto District Court which sentenced him to 12 (twelve) years in prison, a fine of Rp 100.000.000,- (one hundred million rupiahs) in 6 (six) months confinement and criminal addition in the form of chemical castration to convict named Muh. Aris Syukur who had raped 9 (nine) children. ${ }^{17}$ In this case, law enforcement officials consider chemical castration as an additional crime to the perpetrators. This is different from the meaning of the contents of article 81 paragraph (7) which explains that the perpetrators as referred to in paragraph (4) and paragraph (5), namely in the case of intercourse which has caused more than 1 (one) victim, causing the victim to be disturbed psychiatric, infectious diseases suffered, severe injuries, malfunctioning of the victim's reproductive organs even until the victim dies. Perpetrators can be threatened with a criminal sentence of imprisonment of at least 10 (ten) years and a maximum of 20 (twenty) years. ${ }^{18}$ Then be detailed again that the perpetrators who meet these requirements may be subject to treatment in the form of chemical castration carried out after undergoing criminal treatment and afterward only carried out chemical castration treatment. If law enforcement officials consider that chemical castration is an additional crime, ${ }^{19}$ then the meaning in paragraph (9) will be different, which explains that additional penal and treatment are excluded for children. If our see from the contents of the verse, what is meant by additional penal there is in the form of an additional number of crimes. i.e. the criminal plus $1 / 3$ (one-third) of the criminal threat given. While the treatment referred to in paragraph (9) are treatment in the form of chemical castration and electronic detection devices. So if the judge decides the case considers chemical castration as a criminal sanction, it can be said that the judge is considered inaccurate and there is a mistake in deciding a case that is

16 Mardiya, "Penerapan Hukuman Kebiri Kimia Bagi Pelaku Kekerasan Seksual Implementation Of Chemical Castration."

17 Enggran Eko Budianto, "Ini Alasan Hakim Tambah Vonis Kebiri Kimia Ke Predator Anak Di Mojokerto," n.d., https://news.detik.com/Berita-Jawa-Timur/D-4681082/Ini-Alasan-Hakim-Tambah-Vonis-Kebiri-Kimia-KePredator-Anak-Di-Mojokerto.

18 Muhammad Andi Dirgantara et al., "Analisis Yuridis Kebijakan Pemidanaan Dengan Hukuman Kebiri Terhadap Pelaku Pedofilia,” Usu Law Journal 5, no. 1 (2017): 119-27.

19 Adam Yuriswanto and Ahmad Mahyani, "No TitleHukuman Kebiri Sebagai Pidana Tambahan Dalam Tindak Pidana Kejahatan Seksual,” DiH Jurnal Ilmu Hukum 14, no. 27 (2018): 28-40. 
not based on existing regulations because of the position of the chemical castration in positive Indonesian law listed in Government Regulation in Lieu of Law No. 1 of 2016 is a form of treatment and is not a criminal sanction and its position is equal to criminal sanctions whether they are basic or additional crimes, even though it is assessed by the public that treatment in the form of chemical castration have a great impact on the perpetrators.

Obviously, incorporating retribution in the form of chemical castration treatments would reap the benefits and drawbacks in different circles. The inconsistency can be caused by treatments in the form of chemical castration in violation of human rights (HAM) Article 28B (1) of the Republic of Indonesia Constitution of $1945 .{ }^{20}$ Furthermore, it violates the criminal theory adopted by Indonesia today, namely the combined theory (Vernegings Theorien). This combined theory bases the criminal on the principle of retaliation and the principle of defense of public order. There are 2 (two) major groups in this combined theory including: a joint theory that prioritizes retaliation, but retaliation must not exceed the limits of what is necessary and sufficient to be able to maintain public order and a joint theory that prioritizes community protection, but suffering over the fall the crime must not be more severe than the treatment of the convicted person. $^{21}$

Chemical castration treatment currently in force in Indonesia is considered to be a very scary punishment and even more impact than criminal sanctions. Fear felt by the offender when subjected to these chemical castration treatment can be seen from the effects in chemical castration caused by the offender such as: Decreased sexual desire, headaches, nausea and chills, gynecomastia (appearance of breasts in men), weight gain, the ability to erect, phlebitis (a disease that attacks the blood), intestinal bleeding, diabetes. Subsequent inconsistencies also emerged from IDI (Association Doctors of Indonesia), which refused to become executors in the introduction of chemical castration treatment because it was contradictory to the medical code of ethics and the oath of the physician. ${ }^{22}$

20 Messy Rachel Mariana Hutapea, "Penerapan Hukuman Tindakan Kebiri Kimia Dalam Perspektif Hak Asasi Manusia," Jurnal Hukum Magnum Opus 3, no. 1 (2020): 26-34.

21 Ruben Achmad, "Hakekat Keberadaan Sanksi Pidana Dan Pemidanaan Dalam Sistem Hukum Pidana," Legalitas V, no. 2 (2013): 79-104.

22 Atet Sumanto, "Tindakan Kebiri Kimia Bagi Pelaku Tindak Pidana Persetubuhan Dengan Menggunakan Kekerasan Terhadap Anak Di Indonesia,” Perspektif 22, no. 2 (2017): 111-22. 


\subsection{Chemical Castration Is Related To the Principle of the Basic Idea of the Double- Track System in Indonesia}

Indonesian Penal Code has governed penalties and conduct in criminal matters. This is governed in Article 10 of the Penal Code which specifies that a criminal offense consists of basic crime and additional sanctions. Major crimes include capital punishment, parole, imprisonment, fines. Whereas additional offenses are the deprivation of certain freedoms, the confiscation of certain property, the declaration of the verdict of a judge. The purpose of the article is intended so that the judge may not deviate from Article 10 of the Criminal Code in making the verdict. Whereas the treatments in the Indonesian Penal Code are governed in Article 44 which states that a person can not be held accountable to him because his soul is deficient in his body or impaired as a result of disease, the person can not be punished but the judge can order the person to be admitted to a mental hospital. ${ }^{23}$

The basic idea of the double-track system means talking about the basic idea of the penal system, which is the basis of the criminal law framework and the use of witnesses. ${ }^{24}$ This double-track system's basic idea is the equality between criminal sanctions and treatment. Equal penalties and treatment under the double-track system are related to the fact that the element of reproach (through criminal sanctions) and the elements of punishment (through sanctions treatment) are equally important. ${ }^{25}$ The value of criminal sanctions and beneficial steps to optimize the use of both sanctions in a balanced manner, avoid fragmentary sanctions (which overemphasize criminal sanctions) and also ensure the implementation of operational sanctions systems. $^{26}$

According to Alf Ross, the difference between "criminal sanction" and "treatment" is not based on the presence or absence of the first element (suffering), but must be based on the presence or absence of the second element (reproach element). Herbert L. Packer also argues that the level or degree of cruelty is not a characteristic that distinguishes "criminal sanction" and "treatment". The difference must be seen from the purpose and to what extent the role of the perpetrator's treatment in the existence of a crime or treatment. According to Herbert L. Packer,

23 Sudaryono Sudaryono and Natangsa Surbakti, Hukum Pidana Dasar-Dasar Hukum Pidana Berdasarkan KUHP Dan RUU KUHP (Surakarta: Muhammadiyah University Press, 2017).

24 Gita Santika Ramadhani, Barda Nawawi Arief, and Purwoto Purwoto, "Sistem Pidana Dan Tindakan "“Double Track System”” Dalam Hukum Pidana Di Indonesia,” Diponegoro Law Review 1, no. 4 (2012): 1-9.

25 Dwi Wiharyangti, "Implementasi Sanksi Pidana Dan Sanksi Tindakan Dalam Kebijakan Hukum Pidana Di Indonesia," Pandecta 6, no. 1 (2013): 80-85.

26 M Sholehuddin, Sistem Sanksi Dalam Hukum Pidana Ide Dasar Double Track System \& Implementasinya (Jakarta: Raja Grafindo Persada, 2004). 
the main purpose of "action" is to provide benefits or to improve the person concerned. The focus is not on his past or future actions, but on the goal of helping him. ${ }^{27}$

So, the basis for the justification of "treatment" is the view that the person concerned will or maybe better. The main goal is to improve their welfare. Meanwhile, the justification of "criminal sanction" is based on two objectives, including the prevention of crime or undesired conduct or offending conduct and the deserved infliction of suffering on evildoers or retribution for perceived wrong doing. So, in criminal matters, the focus is on wrongdoing or criminal acts that have been committed by the perpetrator. Thus the treatment has a big role and is a condition that must exist, for the existence of "criminal sanction". Furthermore, Herbert L. Packer emphasized that in the case of "criminal sanction" we treat someone because he has done something wrong with the aim, either to prevent the recurrence of the treatment or to wear suffering or both. In the case of "treatment", there is no need to have a relationship with the treatment; we treat the person because we think or think that he or she will get better. We can also hope that the person who is subject to punishment will be better, but it is not because of this that we do so, the main goal is to prevent wrongdoing and not improve the offender. Therefore, between "criminal sanction" and "treatment" must be considered and aimed at a person's future activity to something he has done in the past and the protection of others rather than the betterment of the person being dealt with, then such treatment is called "criminal sanction". In connection with the difference between criminal sanction and treatment, Van Bemmelen stated that the system for including treatment or maatregelen in addition to criminal or straf so that they are "zweispurig" in Holland, is implemented in such a way that the crime also aims at educating criminals, while actions also bring suffering because they are almost always accompanied by deprivation or restriction of freedom. ${ }^{28}$

From the origin of different basic concepts, the distinction between criminal sanctions and treatment can be seen. Criminal sanctions are based on the basic idea: Why is criminal punishment?, while sentences are based on the basic idea: Why is criminal punishment being carried out?, ${ }^{29}$ This means that criminal sanctions are responsive to an treatment while punishments are more forward-looking measures against the treatment perpetrators. Traditionally, it can be said that the distinction between criminal sanctions and behavior

27 Dede Kania, "Pidana Penjara Dalam Pembaharuan Hukum Pidana Indonesia," Yustisia Jurnal Hukum 3, no. 2 (2014): 19-28, doi:10.20961/yustisia.v3i2.11088.

28 Pratiwi Ayu Sri Daulat, "Urgensi Penggunaan Sanksi Hukum Pidana Dalam Konteks Penanggulangan Kejahatan," Hukum Dan Dinamika Masyarakat 16, no. 1 (2018): 79-86.

29 Sholehuddin, Sistem Sanksi Dalam Hukum Pidana Ide Dasar Double Track System \& Implementasinya. 
according to Prof. Sudarto is that the criminal is punishment for the maker's errors, while the treatment is for public safety and the maker's learning or treatment. ${ }^{30}$

Roeslan Saleh said that if a criminal does not just impose a crime in an effort to achieve his goal, it also uses treatment. There are also treatments, however, in contrast to the criminal sanctions. This is intended solely for special prevention. The aim of this treatment is to protect people's safety against people who are a bit dangerous and are going to commit criminal law. ${ }^{31}$ Punishment of treatments directed at criminal offenders based on defense, so that criminal offenders are safer and not just for revenge purposes. Treatment is also forward-looking so that the victims try to better realize that what has been done is wrong and violates the law, so it won't be repeated later. Based on H.L. Packer about treatment, the primary purpose of therapy is to support the individual being treated. The emphasis is not on his behavior, history or future, but on supporting him. ${ }^{32}$

Examples of the application of criminal sanctions and treatment in special laws outside the Criminal Code include Law Number 32 of 2009 concerning Environmental Protection and Management which adheres to double-track system in imposing sanctions. Article 98 through Article 118 of Law number 32 of 2009 concerning Environmental Protection and Management regulates criminal penalties in the form of imprisonment, confinement, and fines. Whereas the regulation on sanctions for treatment can be seen from Article 119 of Law number 32 of 2009 concerning Environmental Protection and Management which explains that the treatment is in the form of deprivation of profits obtained from treatments, closure of all or part of the place of business and/or treatment, improvement due criminal offense, the obligation to do what was neglected without rights; and/or company placement under a maximum of 3 (three) years. Furthermore, Law Number 35 of 2009 concerning Narcotics also adopts double-track system in imposing sanctions. This can be seen from Articles 111 to 144 and 147. These articles constitute the imposition of sanctions in the form of capital punishment, imprisonment, confinement, and fines. While sanctions for treatment are contained in Chapter IX starting from Article 53 to Article 56 of Law Number 35 of 2009 concerning Narcotics in the form of rehabilitation. ${ }^{33}$

\footnotetext{
30 Muladi and Arief, Teori-Teori Dan Kebijakan Pidana.

31 Marcus Priyo Gunarto, “Asas Keseimbangan Dalam Konsep Rancangan Undang-Undang Kitab Undang-Undang Hukum Pidana," Mimbar Hukum 24, no. 1 (2012): 84-97.

32 Muladi and Arief, Teori-Teori Dan Kebijakan Pidana.

33 Wiharyangti, "Implementasi Sanksi Pidana Dan Sanksi Tindakan Dalam Kebijakan Hukum Pidana Di Indonesia."
} 
From example above, we can know that double-track criminal system of indonesia explained that between criminal sanctions and treatment constitute a breakthrough regarding Indonesian penalties which were initially oriented only to deploying the perpetrators but with the presence of this double-track system the aim of Indonesian penalties is not only to enact but the perpetrators to make improvements, recovery to the perpetrators as adhered to the combined theory based on aspects of retaliation and defense of public order. However, in its development, there is a rule that creates confusion and inconsistency in the application of penalties between criminal sanctions and treatment as regulated in the double-track system. That rule is in Law No. 17 of 2016 concerning the stipulation of Government Regulation in Lieu of Law number 1 of 2016 concerning Amendment to Law Number 23 of 2002 concerning Child Protection.

This statute explains the existence of criminal sanctions and treatment including imprisonment, namely by adding criminal sanctions, Including imprisonment, civil fines and the presence of chemical castration penalties. The presence of these two forms of sanctions is a problem related to the regulation of sanctions, the severity of sanctions and the formulation of sanctions themselves. But in reality, in the development of society, it is known that the penal sanctions that are regulated are in fact not very impactful and are even more feared by the public ie castration chemistry treatment with the explanation that chemical castration treatment is a new legal development that could harm the victims and is full of confusion and contradictory in deciding the types and forms of punishment for compliance by the authorities. To overcome the complexity of the penalty stipulation to law, it is necessary to establish a penalty pattern as a guide for the planning of the penalty system so that contradictions do not occur in terms of enforcement.

Sholehuddin explained that the pattern of punishment is different from the guidelines of the criminal code. The term pattern refers to a reference or guideline for composing a criminal for a rule (the policy stage of the law) whereas the criminal guideline is a guideline for imposing/applying a criminal to a judge (the stage of judicial procedure). ${ }^{34}$ The punishment pattern will function as a legislative guideline for lawmakers in the above explanation, and a criminal guideline is a guideline for judges' jurisdictionIn-Law No. 17 of 2016, the problem lies in the pattern of convictions that have an impact on criminal guidelines because the making of the law is based solely on a one-sided view that does not think extensively to achieve the goal of punishment, resulting in inconsistency in criminal proceedings.

34 Sholehuddin, Sistem Sanksi Dalam Hukum Pidana Ide Dasar Double Track System \& Implementasinya. 
Based on the concept of the double-track system, chemical castration treatment was deemed to be excessive in understanding the basic concept of the double-track system, implying that there is no equivalent punishment among sanctions and treatment. Chemical castration treatment in the form of physical punishment is known as a penalty because it can cause disease and ways of taking the right to freedom and even the perpetrator's right to existence. This contradicts the meaning of the law itself, which focuses on restoring public or private physical, emotional and certain disabilities. Then, when assessing criminal penalties or treatments, consideration must be given to the nature of the offenders (individuals or corporations) to achieve the aim of fair justice effectively, but with the absence of such laws lead to discrimination in the care of victims who may be unhappy in the future.

\section{Conclusions}

The conclusion to be drawn from the above discussion, namely; first: adding punishment in the form of chemical castration will reap the benefits and disadvantages of certain circles. The contradiction can be initiated by treatment in the form of chemical castration in violation of human rights (HAM) Article 28B(1) of the Republic of Indonesia Constitution of 1945, In other words, everyone has the right to form a family and to continue to have offspring through legal marriage. It also contradicts Indonesia's existing criminal theory, namely the combination theory which prioritizes retaliation, but retaliation must not surpass the limits of what is necessary and sufficient to maintain public order and a common theory that prioritizes community security, But the crime must not be more severe than the convicted person's treatment. As specified in Government Regulation in Location of Law Number 1 of 2016, the role of chemical castration in Indonesian positive law is a treatment, not a criminal sanction. Nevertheless if it looks at the effects of chemical castration, the task of chemical castration is considered a criminal penalty. Second: chemical castration treatment is considered to be excessive in the understanding of the basic principles of the double-track system, implying that there is no equality of criminal sanctions and treatment. Chemical castration treatment contradicts the meaning of the sanction itself, which aims to restore certain public or private circumstances to physical, psychological and psychological conditions. 


\section{References}

Achmad, Ruben. "Hakekat Keberadaan Sanksi Pidana Dan Pemidanaan Dalam Sistem Hukum Pidana.” Legalitas V, no. 2 (2013): 79-104.

Arief, Barda Nawawi. Bunga Rampai Kebijakan Hukum Pidana. Semarang: Prenadamedia Group, 2018.

Budianto, Enggran Eko. "Ini Alasan Hakim Tambah Vonis Kebiri Kimia Ke Predator Anak Di Mojokerto,” n.d. https://news.detik.com/Berita-Jawa-Timur/D-4681082/Ini-Alasan-HakimTambah-Vonis-Kebiri-Kimia-Ke-Predator-Anak-Di-Mojokerto.

Burhanuddin, Aisyah Amini. "Penerapan Sistem Dua Jalur Dalam Putusan Perkara Anak Yang Berhadapan Dengan Hukum.” Al Hikam 2, no. 1 (2018): 34-49.

Daulat, Pratiwi Ayu Sri. "Urgensi Penggunaan Sanksi Hukum Pidana Dalam Konteks Penanggulangan Kejahatan.” Hukum Dan Dinamika Masyarakat 16, no. 1 (2018): 79-86.

Dirgantara, Muhammad Andi, Syafruddin Kalo, Alvi Syahrin, and Chairul Bariah. "Analisis Yuridis Kebijakan Pemidanaan Dengan Hukuman Kebiri Terhadap Pelaku Pedofilia.” Usu Law Journal 5, no. 1 (2017): 119-27.

Eddyono, Supriyadi Widodo, Ahmad Sofian, and Anugerah Rizki Akbari. Menguji Euforia Kebiri Catatan Kritis Atas Rencana Kebijakan Kebiri (Chemical Castration) Bagi Pelaku Kejahatan Seksual Anak Di Indonesia. Jakarta Selatan: Institue For Criminal Justice Reform Ecpat Indonesia Mappi FH UI Koalisi Perempuan Indonesia Aliansi 99 Tolak Perppu Kebiri, 2016.

Gunarto, Marcus Priyo. “Asas Keseimbangan Dalam Konsep Rancangan Undang-Undang Kitab Undang-Undang Hukum Pidana.” Mimbar Hukum 24, no. 1 (2012): 84-97.

Hasanah, Nur Hafizal, and Eko Soponyono. "Kebijakan Hukum Pidana Sanksi Kebiri Kimia Dalam Perspektif Ham Dan Hukum Pidana Indonesia.” Jurnal Magister Hukum Udayana (Udayana Master Law Journal) 7, no. 3 (2018): 305-17.

Hutapea, Messy Rachel Mariana. "Penerapan Hukuman Tindakan Kebiri Kimia Dalam Perspektif Hak Asasi Manusia.” Jurnal Hukum Magnum Opus 3, no. 1 (2020): 26-34.

Ikhsanudin, Arief. "KPAI Sebut Kasus Kekerasan Seksual Anak Meningkat Akibat Pengaruh Digital,” n.d. https://news.detik.com/Berita/D-4640789/Kpai-Sebut-Kasus-KekerasanSeksual-Anak-Meningkat-Akibat-Pengaruh-Digital.

Kania, Dede. "Pidana Penjara Dalam Pembaharuan Hukum Pidana Indonesia." Yustisia Jurnal Hukum 3, no. 2 (2014): 19-28. doi:10.20961/yustisia.v3i2.11088. 
Krismiyarsi, Krismiyarsi. “Kebijakan Sanksi Kebiri Kimia Bagi Pelaku Kekerasan Seksual Terhadap Anak Kajian Politik Hukum Pidana.” Seminar Nasional Hukum Universitas Negeri Semarang 4, no. 1 (2018): 90-109.

Mardiya, Nuzul Qur’aini. "Penerapan Hukuman Kebiri Kimia Bagi Pelaku Kekerasan Seksual Implementation Of Chemical Castration.” Jurnal Konstitusi 14, no. 1 (2017): 214-33.

Mokale, Junita. "Pedofilia Sebagai Salah Satu Bentuk Kejahatan Kekerasan Seksual Terhadap Anak." Lex Crimen 2, no. 5 (2013): 98-107.

Muladi, Muladi, and Barda Nawawi Arief. Teori-Teori Dan Kebijakan Pidana. Bandung: Alumni, 2010.

Munthe, Cesar Antonio. "Relevansi Sanksi Kebiri Kimia Dalam Perpu No. 1 Tahun 2016 Tentang Perubahan Kedua Atas Undang-Undang Nomor 23 Tahun 2002 Tentang Perlindungan Anak Terhadap Tujuan Pemidanaan.” Justitia Et Pax 32, no. 2 (2017): 10622.

Ramadhani, Gita Santika, Barda Nawawi Arief, and Purwoto Purwoto. "Sistem Pidana Dan Tindakan “"Double Track System”” Dalam Hukum Pidana Di Indonesia.” Diponegoro Law Review 1, no. 4 (2012): 1-9.

Ratkoceri, Vedije. "Chemical Castration As A Security Measure In The Criminal Legislation Of The Republic Of Macedonia.” International Journal Of Social Sciences And Education Research 3, no. 2 (2017): 357-60.

Sholehuddin, M. Sistem Sanksi Dalam Hukum Pidana Ide Dasar Double Track System \& Implementasinya. Jakarta: Raja Grafindo Persada, 2004.

Sudaryono, Sudaryono, and Natangsa Surbakti. Hukum Pidana Dasar-Dasar Hukum Pidana Berdasarkan KUHP Dan RUU KUHP. Surakarta: Muhammadiyah University Press, 2017.

Sumanto, Atet. “Tindakan Kebiri Kimia Bagi Pelaku Tindak Pidana Persetubuhan Dengan Menggunakan Kekerasan Terhadap Anak Di Indonesia.” Perspektif 22, no. 2 (2017): 11122 .

Tashandra, Nabila. "DPR Sahkan Perppu Kebiri Menjadi Undang-Undang," n.d. https://nasional.kompas.com/Read/2016/10/12/13333281/Dpr.Sahkan.Government Regulation In Lieu Of Law.Kebiri.Menjadi.Undang-Undang?Page=All.

Tullio, Elizabeth M. "Chemical Castration for Child Predators: Practical, Effective, and Constitutional." Chapman Law Review 13, no. 19 (2010): 191-220.

Widayati, Lidya Suryani. "Pengebirian Sebagai Upaya Perlindungan Anak Dari Kekerasan 
Seksual.” Info Singkat Hukum 7, no. 20 (2015): 1-4.

Wiharyangti, Dwi. "Implementasi Sanksi Pidana Dan Sanksi Tindakan Dalam Kebijakan Hukum Pidana Di Indonesia." Pandecta 6, no. 1 (2013): 80-85.

Yuriswanto, Adam, and Ahmad Mahyani. "No TitleHukuman Kebiri Sebagai Pidana Tambahan Dalam Tindak Pidana Kejahatan Seksual.” DiH Jurnal Ilmu Hukum 14, no. 27 (2018): 2840 . 